\title{
Structural Interdicts for Socio-economic Rights: What the Kenyan Jurisprudence Has Missed
}

\author{
Strathmore Law Clinic (SLC)*
}

\begin{abstract}
The enforcement of socio-economic rights is unique as it necessitates positive action in policy-making and bears budgetary implications. Consequently, to prevent such enforcement from exceeding the scope established by the doctrine of 'separation of powers', because policy-making and budgetary allocation are under the executive and legislature respectively, the Kenyan Court of Appeal was hesitant to apply structural interdicts in the case of Kenya Airports Authority v Mitu-Bell Welfare Society $\& 2$ others. This decision has outlawed structural interdicts from the Kenyan jurisprudential landscape and has failed to give a viable alternative judicial approach that should guide subsequent courts in enforcing socio-econom$i c$ rights. This study looks into the origin and models of structural interdicts so as to analyse and critique this Court of Appeal's decision by showing how the Court could have applied structural interdicts in the enforcement of socio-economic rights without impinging on the doctrine of separation of powers. This will be achieved through the use of literature review.
\end{abstract}

Key words: socio-economic rights, structural interdicts, separation of powers, progressive realisation of rights and Mitu-Bell case

\section{Introduction}

As granted by the new constitutional dispensation, in Article 43, socioeconomic rights enjoy protection and are now subject to judicial enforcement.

* The author is a student-run institution. Contributors to this article are LL.B students at Strathmore University Law School, Nairobi. They are: Mr Arnold Nciko, Ms Bertha Odawa, Ms Michelle Malonza, Ms Mariam Malik, Mr Waya Ndegwa, Ms Shirlene Ndenga, Ms Joy Muya, Ma Liza Chula, Ms Eden Gatuiku, Ms Wachuka Musomba, Ms Faith Thuku, Ms Christine Njane, Ms Cynthia Njagi, Ms Stacie Manani, Ms Cindy Ajumbo, Ms Gladwinnie Ngatia, Ms Nusrah Perera and Ms Daisy Chirchir. 
These rights obligate the State to take special deliberative action whose judicial enforcement requires innovative and unorthodox remedial propositions. These ensure democratic attention to crucial interests that have otherwise been overlooked or breached. The most revolutionary remedy developed in accomplishing this without the judicial usurpation of powers is the use of structural interdicts. A structural interdict is a supervisory order through which a court controls compliance with its order. ${ }^{1}$ It targets priority-setting in prompting the government to observe its constitutional obligations by refraining from the unreasonable neglect of socio-economic rights.

Unfortunately, the use of structural interdicts was outlawed in Kenya Airports Authority v Mitu-Bell Welfare Society \& 2 others (hereinafter the MituBell case). ${ }^{2}$ Despite this, the Court of Appeal has failed to provide alternative guiding principles to help future courts in enforcing socio-economic rights. ${ }^{3}$ Thus, the central claim of this study is that the Kenyan judiciary should embrace comparative jurisprudence so as to enforce the socio-economic rights protected under the Constitution of Kenya 2010 (hereafter the Constitution) without impinging on the doctrine of separation of powers. ${ }^{4}$

The Constitution is possibly one of Kenya's greatest treasures. Perhaps this is because it features an expansive and exhaustive Bill of Rights which has ushered in a wave of hope where citizens had been previously subjected to rife violation of human rights since the country's independence. ${ }^{5}$ Commendably, the Constitution has, in conformity with international obligations and to the benefit of its citizens, incorporated justiciable socio-economic rights that were unavailable under the old constitutional order. Under Chapter IV of the Constitution, Article 43 lists the socio-economic rights such as the right to health; adequate housing and sanitation; adequate food; clean and safe water; social security; and education ${ }^{6}$ as integral in the promotion of social justice. ${ }^{7}$

1 Mbazira C, 'From ambivalence to certainty: Norms and principles for the structural interdicts in socio-economic-economic rights litigation in South Africa', 24 South African Journal on Human Rights, 2008, 4.

2 Kenya Airports Authority v Mitu-Bell Welfare Society \& 2 others (2016) eKLR.

Kenya Airports Authority v Mitu-Bell Welfare Society \& 2 others (2016) eKLR.

Article 20(2) (c) and 43, Constitution of Kenya (2010).

Ambani JO and Mbondenyi K, A new era in human rights promotion and protection in Kenya? An analysis of the salient features of the 2010 Constitution's Bill of Rights, (eds) Pretoria University Law Press, Pretoria, 2015, 17-18.

Article 43, Constitution of Kenya (2010).

Article 19(2), Constitution of Kenya (2010). 
This paradigm shift in constitutional drafting makes recourse mechanisms available, through adjudication processes, where socio-economic rights have been contravened. Article 21 (1) of the Constitution secures the tripartite typology of the duty to 'respect, protect and fulfil' the rights and fundamental freedoms in the Bill of Rights. ${ }^{8}$ This imposes upon the State a negative duty not to interfere with the rights of any individual and to regulate the behaviour of private persons in ensuring that no infringement of rights accrues. It also asserts a corresponding positive duty to institute other measures, including judicial, in the realisation of these rights.' Sub-article 2 further affirms that 'the State shall take legislative, policy and other measures...to achieve the progressive realisation of the rights guaranteed under Article 43. ${ }^{10}$ Article 22 goes on to speak directly on judicial enforcement, extending the right to every person to institute a claim in court where a right or fundamental freedom 'has been denied, violated or infringed, or is (otherwise) threatened'. ${ }^{11}$

Under Article 23, authority is extended to the courts to hear and determine applications pertaining to the contravention of a right or fundamental freedom in the Bill of Rights. ${ }^{12}$ The court is granted wide judicial discretion under this Article to give, inter alia, any 'appropriate relief' it deems fit in administering corrective measures. ${ }^{13}$ In addition, under Article 165 the High Court has 'broad rights-based review and remedial powers over all actions and inactions of the State'. ${ }^{14}$ (Emphasis author's own)

It is important, however, to note that the enforcement and adjudication of socio-economic rights has not been without difficulty, not in the least on account of their novelty in the Kenyan jurisdiction. This is contrary to their alternate yet indivisible counterparts: political and civil rights, that have enjoyed a relatively long history of judicial application in Kenya. The realisation of socio-economic rights requires State responsiveness whose enforcement would in turn require the Judiciary to urge State action in promoting these rights. For instance, a court

8 Article 21(1) states, 'It is a fundamental duty of the State and every State organ to observe, respect, protect, promote and fulfil the rights and fundamental freedoms in the Bill of Rights.'

9 Miyawa M, 'Judicial Enforcement of Socio-economic-Economic Rights: A Case for Dialogic Approach in Crafting Appropriate Judicial Remedies' Unpublished LLM Thesis, University of Nairobi, Nairobi, 2011, 40.

10 Same standard set out in the International Covenant on Economic, Social and Cultural Rights (ICESCR).

11 Article 22(1), Constitution of Kenya (2010).

12 Article 23(1), Constitution of Kenya (2010).

13 Article 23(3), Constitution of Kenya (2010).

14 Miyawa M, 'Judicial Enforcement of Socio-economic-Economic Rights: A Case for Dialogic Approach in Crafting Appropriate Judicial Remedies', 60. 
may compel the Executive to come before it within a prescribed period with policies in place to guarantee one's right to food. Such a check on the functions of government would therefore enhance the protection, preservation and fulfilment of rights of all its people. At the same time, allowing the Judiciary to encroach upon the functions of the other two traditional arms of government, as it deems fit, would be destructive in placing the courts in the 'position of overseeing largescale bureaucratic institutions'. ${ }^{15}$

Given this conundrum, there then emerges the need to ensure the enforcement of socio-economic rights while simultaneously preserving the doctrine of separation of powers. Thus far, the position in the Kenyan judiciary provides no guidance as to how this balance can be achieved as demonstrated by the infamous Mitu-Bell Court of Appeal decision. ${ }^{16}$ Consequently, Section I of this study being this introduction, Section II looks into the implication, the origin and the models of structural interdicts. Section III analyses the Court of Appeal's decision in the MituBell. Finally, the discussion ends in Section IV with critiques of this decision in an attempt to provide the balance between socioeconomic rights and the doctrine of separation of powers that could have been achieved through the use of structural interdicts.

\section{Structural Interdicts for Socio-Economic Rights: Origin, Models and Implication}

\section{i. Origin}

The history of structural interdicts can be traced back to Brown v. Board of Education of Topeka, Shawnee County, Kansas. This is the landmark United States of America (USA) Supreme Court case in which it was held that state laws establishing separate public schools for black and white students were unconstitutional. ${ }^{17}$ This was the first case in which astructural interdict-type remedy was implemented, and is commonly referred to as the source of structural interdicts in constitutional litigation. ${ }^{18}$ In Brown I of 1954, the named plaintiff;

15 Sunstein C, 'Social and Economic Rights? Lessons from South Africa' Coase- Sandor Institute for Law and Economics, John M. Olin Law and Economics Working Paper No. 124, 2001, 3 — https:// chicagounbound.uchicago.edu/cgi/viewcontent.cgi?article=1454\&context=law_and_economic on 8 November 2018.

16 Kenya Airports Authority v Mitu-Bell Welfare Society \& 2 others (2016) eKLR.

17 Brown v Board of Education (1954), The Supreme Court of the United States.

18 Rycroft A \& Bellangere 'A judicial innovation and the delinquent state: a note on the state and Mfezeko Zuba and 23 similar cases', 20 South African Journal on Human Rights,2004, 326. 
Linda Brown, was an African-American child who resided in the State of Kansas. She was denied admission to a public school attended only by white children as Kansas state law permitted segregation according to race. Linda Brown was forced to attend a school which was solely constituted of African-American students. Brown sought the aid of courts arguing that segregation deprived her of the 'equal protection of the laws' guaranteed by the Fourteenth Amendment of the United States Constitution. ${ }^{19}$ The State Courts upheld the segregation of the public schools under the 'separate but equal' doctrine of Plessy ${ }^{20}$ holding that 'equality of treatment was accorded when both races are provided substantially equal facilities', ${ }^{21}$ despite the fact that black students were not permitted to go to the same schools attended by white students.

However, in Brown II - the appeal to the Supreme Court in 1955 - the Court struck down the notion of 'separate but equal' education and ended legalised segregation in USA's public schools, ordering desegregation 'with all deliberate speed'.22 The Court further ordered that the cases be returned to the lower courts, which were better positioned to supervise the desegregation process. ${ }^{23}$ The order effectively required the different school authorities to remedy the situation themselves. Moreover, the Court also declared that the lower courts should 'consider the adequacy of any plans the defendants may propose' in order to bring about transformation in the schooling system by desegregating it and that the lower courts would retain jurisdiction over these cases to ensure effective compliance. ${ }^{24}$ Mbazira states that many school authorities did not comply with court orders dealing with desegregation, but that the ongoing jurisdiction allowed courts to 'intervene more intrusively' and to give further directions aimed at ensuring compliance. ${ }^{25}$

19 See Fourteenth Amendment, United States Constitution (1788), which states that "All persons born or naturalized in the United States, and subject to the jurisdiction thereof, are citizens of the United States and of the State wherein they reside. No State shall make or enforce any law which shall abridge the privileges or immunities of citizens of the United States; nor shall any State deprive any person of life, liberty, or property, without due process of law; nor deny to any person within its jurisdiction the equal protection of the laws."

20 See Plessy v Ferguson (1896), The Supreme Court of the United States where the Court upheld the constitutionality of racial segregation laws for public facilities as long as the segregated facilities were equal in quality - a doctrine that came to be known as 'separate but equal'.

21 Brown v Board of Education of Topeka (1954), The Supreme Court of the United States.

22 Rycroft A \& Bellangere 'A judicial innovation and the delinquent state: a note on the state and Mfezeko Zuba and 23 similar cases', 20 South African Journal on Human Rights,2004, 327.

23. Brown v Board of Education of Topeka (1955), The Supreme Court of the United States.

24 Brown v Board of Education of Topeka (1955), The Supreme Court of the United States.

25 Mbazira C, Litigating socio-economic rights in South Africa: a choice between corrective and distributive justice, 2009, 180. See also Michelman F 'Constitutionally binding social and economic rights as a compelling idea: reciprocating perturbations in liberal and democratic constitutional 
When assessing the Supreme Court's rationale in applying structural interdicts, one notes that it dealt with the question of how the federal courts were to desegregate the schools in accordance with the mandate of Brown $I$, decided the year before. By declaring racial segregation in public education unconstitutional, Brown II not only dealt a hard blow to the doctrine of 'separate but equal'; as well as completely transforming much of the worlds' perspective on race; but it also revolutionised the manner in which the United States judiciary viewed its role. ${ }^{26}$ Instead of merely declaring racial segregation in the school system to be in grave violation of the United States Constitution, and then leaving it in the hands of the educational authorities to make the necessary corrections, the Supreme Court creatively invented the structural interdict as an entirely new form of judicial remedy. ${ }^{27}$ Since then, numerous courts have employed structural interdicts in a variety of ways to foster public school desegregation, ${ }^{28}$ to reform state prisons ${ }^{29}$ and mental hospitals, ${ }^{30}$ to address legislative reapportionment ${ }^{31}$ and other institutional reform of housing authorities ${ }^{32}$ and employment discrimination. ${ }^{33}$ Many government institutions throughout the United States have been, or continue to be, subject to the supervision of district courts, through structural interdicts. ${ }^{34}$

\section{ii. Models}

The nature and function of structural interdicts differ today on a case-tocase basis and therefore, a number of models of this remedy are available, all of

visions' in García H, Klare K \& Williams L (eds) Social and Economic Rights in Theory and Practice (2015) 277, 288-289.

26 Sachs A in Godden L and Tehan M (eds), Comparative perspectives on communal lands and individual ownership: sustainable futures, Routledge, 2010.

27 Godden L and Tehan M, Comparative perspectives on communal lands and individual ownership.

28 See Cooper v Aaron (1958), The Supreme Court of the United States: where the Supreme Court refused to permit a two-and-a-half-year delay in desegregating schools in Little Rock, Arkansas. See also St. Helena School Bd. v Hall (1962), The Supreme Court of the United States in which the court invalidated a Louisiana statute permitting local school boards to close the public schools and rent out the buildings for use as private schools.

29 See Hutto v Finney (1978), The Supreme Court of the United States.

30 See Pennhurst State School and Hospital v Holderman (1981), The Supreme Court of the United States: where the Supreme Court held that the federal statute in question did not confer any substantive rights to 'minimally adequate habitation.'

31 See Baker v Carr (1962), The Supreme Court of the United States.

32 See Gautreaux v Chicago Housing Authority (1969), The Supreme Court of the United States.

33 See Kirkland $v$ New York State Department. of Correctional Services (1974), The United States Court of Appeals for the Second Circuit.

34 Zaring D, 'National rulemaking through trial courts: the big case and institutional reform,' 51 UCLA Law Review, 2004, 1015, 1021. 
which are intended to pave the way for a proper enforcement of socio-economic rights. The 'report back to court' model is the one that was developed in the Brown case and is the most commonly used. According to this model, courts have specifically focused on 'meaningful engagement'.

Essentially, for this model, there are stages which are procedurally followed until the court is satisfied that the violation of the socio-economic right has been remedied. The court first issues a declaration identifying how the government, or part of it, has violated or infringed on a person or group's constitutional rights. Secondly, the court mandates the government to comply with its constitutional obligations. Thirdly, the government is ordered to prepare and submit a thorough report to the court on a specific date. This report will usually detail a plan to remedy or continuously mitigate the harm caused by the violations. Fourthly, the court evaluates whether the proposed plan sufficiently remedies the harm caused by the constitutional infringement and whether the government is complying with its obligations. And finally, the court grants a final order approving and integrating the plan as well as any court-ordered amendments. As a result of this particular step, any failure to adhere to this plan amounts to contempt of court. ${ }^{35}$ These stages clearly show that structural interdicts should not override the doctrine of separation of powers. The court should always leave a State organ with the discretion to decide on how to respect and promote socio-economic rights through the means that are available to them and not impose a particular method.

It is along these lines that Moyo argues that the main reason why structural interdicts should be implemented by courts is because 'they constitute a valuable remedy for specific types of socio-economic rights violations and their use should not be discouraged on the argument of restrictive conceptions of the separation of powers doctrine and judicial competence. ${ }^{36}$ The foundation of this argument lies in the fact that courts have to balance enforcing orders and making sure they do not create policies which belong in the sphere of the executive or legislative arms of government. Courts must find a balance between infringing on the executive's or the legislature's role and implementing structural interdicts within its jurisdiction.

\footnotetext{
35 See generally Currie I and De Waal J, The Bill of Rights Handbook, 6, Juta \& Company, Western Cape, 2013.

36 Moyo K, 'The jurisprudence of the South African Constitutional Court on socio-economiceconomic rights' 16.
} 
Other models include the bargaining model where the parties negotiate to agree on the appropriate remedy, such a remedy is self-imposed and not court-imposed; ${ }^{37}$ the legislative or administrative hearing model, which allows for informal public participation by interested parties who may not be party to the suit; ${ }^{38}$ the expert remedial formulation model involves experts mandated to develop the remedial plan and is the only model that encroaches upon the powers of the executive. This will be expounded on further below. The consensual remedial formulation model, similar to the bargaining model, requires the parties to exchange their views and concerns with the aim of agreeing on a suitable remedy. ${ }^{39}$

All these models can be categorised as mandatory interdicts. ${ }^{40}$ There exists another category known as prohibitory interdicts. A prohibitory interdict is meant to prevent a threatened interference to access of a socio-economic right. ${ }^{41}$ Using a hypothetical example, if the government formulates a new policy that will negatively affect the right to housing of its citizens, then a prohibitory interdict can prevent the government from implementing such a policy.

It is worth noting that prior to the Mitu-Bell case, Kenyan courts made pronouncements on structural interdicts. For instance, in the case of Moi University $v$ Council of Legal Education, the High Court applied the 'reportback-to-court' model. The Court appreciated that the applicant was entitled to appropriate relief according to Article 23 of the Constitution, which they construed must be an effective remedy to ensure the rights entrenched in the Constitution are properly upheld and enforced. In accordance with this, the court recognised structural interdicts highlighting five elements common to these interdicts:

37 The case of Fose $v$ Minister of Safety and Security (1997), Constitutional Court of South Africa. This case addressed what 'appropriate remedy' means as the effective remedy. See also Mbazira C, Litigating socio-economic rights in South Africa: a choice between corrective and distributive justice, 183-184.

38 Mbazira C, Litigating socio-economic rights in South Africa: a choice between corrective and distributive justice, 187.

39 -<https://hsf.org.za/publications/hsf-briefs/structural-interdicts-an-effective-means-of-ensuringpolitical-accountability> on 6 June 2018.-<https://hsf.org.za/publications/hsf-briefs/structuralinterdicts-an-effective-means-of-ensuring-political-accountability> on 6 June 2018.

40 Moyo K, 'The jurisprudence of the South African Constitutional Court on socio-economiceconomic rights' 15. A mandatory interdict is a court order that must be complied with based on the instructions of the Court.

${ }^{41}$ Moyo K, 'The jurisprudence of the South African Constitutional Court on socio-economiceconomic rights' 15. 
a.) The court issues a declaration identifying how the government has infringed an individual or group's constitutional rights or failed to comply with its constitutional obligations.

b.) The court mandates government compliance with constitutional responsibilities.

c.) The government is ordered to prepare and submit a comprehensive report, usually under oath, to the court on a pre-set date, which should explain an action plan for remedying non-compliance with said rights or obligations.

d.) Once the report is presented, the court evaluates whether the proposed plan does indeed remedy the infringement.

e.) If approved, a final order integrating the government plan and any court-ordered amendment is issued. Non-compliance thereafter amounts to contempt of court. ${ }^{42}$

The court went ahead to emphasise that structural interdicts improve government accountability and therefore provide a more fundamentally fair outcome than other remedies in Economic and Social Rights litigation. Providing relief to all members of a similarly situated class does this, according to the court, whether or not any given individual has the resources to litigate their own case.

The court, however, did not grant a structural interdict but instead issued an order suspending the declaration of the invalidity (illegality) in the constitution of the council for a period of sixty days. This, according to the Court, was to facilitate proper constitution, which was a minor breach that could be remedied without invalidating the said council's whole enactment therefore depriving the society of useful decisions made by such council regarding legal education. Therefore, providing for socio-economic rights, the Constitution facilitates recourse to structural interdicts in order to enforce them. This may be seen in Article 21 which affirms that 'the State shall take legislative, policy and other measures to achieve the progressive realisation of socio-economic rights'. ${ }^{43}$

\footnotetext{
42 Moi University v Council of Legal Education (2015), eKLR.

43 Article 21, Constitution of Kenya (2010).
} 


\section{iii. Implication}

To enforce socio-economic rights without infringing on the doctrine of separation of powers, many jurisdictions have embraced structural interdicts. Fundamentally, they require the government to rectify a breach of a fundamental right under the supervision of the court; hence they can also be referred to as supervisory orders. ${ }^{44}$ It should be borne in mind that structural interdicts are usually used as a remedy for eliminating systemic violations of socio-economic rights where constitutional obligations exist. Similar to orders of mandamus, they focus on adjusting future behaviour of the violator rather than compensating for past wrongs. Additionally, a prominent feature of structural interdicts is that the court retains jurisdiction over the matter. ${ }^{45}$ This is, however, is in contradiction to the doctrine of functus officio, which states that the court has no further official duty or legal effect once it has made its decision. ${ }^{46}$ Retention of jurisdiction by the court assists parties to bring to the attention of the court orders which they think are not being adhered to. In the same way, structural interdicts also help parties to whom the orders have been given to seek clarity about the orders. ${ }^{47}$

The following section analyses the Kenyan Court of Appeal decision in the Mitu-Bell case which outlawed structural interdicts as a means to enforce socioeconomic rights in the Kenyan jurisprudential landscape and attempts to see whether the Court could have accommodated structural interdicts in this case.

\section{The Mitu-Bell Case in the Court of Appeal: Analysis}

This case was initially instituted in the High Court where the respondents, who were initially the petitioners, filed a petition on behalf of residents of a slum dwelling known as Mitumba Village. They were evicted from the premises belonging to the appellant where they lived as squatters and had erected residential and business structures, as well as educational facilities. Upon eviction, the residents were not provided with alternative shelter arrangements and so

\footnotetext{
44 -<http://www.polity.org.za/article/the-nature-and-role-of-the-structural-interdict-supervisoryorder-its-use-and-appropriateness-as-a-remedy-in-the-nkandla-judgment-2016-04-11> on 5 June 2018.

45 Mbazira C, 'From ambivalence to certainty: Norms and principles for the structural interdicts in socio-economic-economic rights litigation in South Africa', 4.

46 Merriam Webster Dictionary, 4th ed.

47 Mbazira C, 'Litigating Socio-economic-Economic Rights in South Africa- A choice between corrective and retributive justice', Pretoria University Law Press, Cape Town, 2009, 181.
} 
the respondents claimed it was an infringement on their social, economic and constitutional right to accessible and adequate housing. ${ }^{48}$

The Court of Appeal examined the decision of the High Court, which was two-fold. First, that the appellant should provide within 60 days an affidavit detailing the policies and programmes of how they seek to address the right to shelter and of access to housing of marginalised groups such as those living in informal settlements. ${ }^{49}$ Second, that copies of such policies and programmes be issued to the residents of Mitumba Village and other relevant state agencies as well as civil society organisations that the parties to the matter at hand agree upon as having the requisite knowledge and expertise in the area of housing and shelter provision. It was the High Court's assertion that Pamoja Trust should be part of such civil society organisations which are to assess the cogency and efficacy of such policies and programmes. ${ }^{50}$

The issues for determination before the Court of Appeal were that the High Court judge erred in her decision by delegating her judicial functions to unnamed state agencies and civil society organisations, including Pamoja Trust. The other ground for the appeal was the fact that the appellant's statutory mandate does not include attending to the settlement of landless Kenyans.

Relying on Ndora Stephen v Minister for Education \& 2 Others, the Court of Appeal conceded that Justice Mumbi correctly observed that the formulation of policies and their implementation falls under the ambit of the executive. ${ }^{51}$ However, the Court of Appeal maintained that questions which are in their nature exclusively political should never be adjudicated upon by courts. The Court went further to state that courts should practice self-restraint and discipline in adjudicating government or executive policy issues, a fact which Justice Mumbi failed to appreciate. ${ }^{52}$ Further, the Court of Appeal relied on the political question doctrine, which connotes that a court has no jurisdiction to make orders relating to policy formulation, or give guidelines on who should participate in the formulation of government policy. ${ }^{53}$

In light of the above analysis, the Court of Appeal's response to the issues of determination before it was as follows: that first, Justice Mumbi erred in her

\footnotetext{
Mitu-Bell Welfare Society v Attorney General \& 2 others (2013) eKLR. Mitu-Bell Welfare Society v Attorney General and 2 others (2013) eKLR. Kenya Airports Authority v Mitu-Bell Welfare Society \& 2 others (2016) eKLR. Kenya Airports Authority v Mitu-Bell Welfare Society \& 2 others (2016) eKLR. Kenya Airports Authority v Mitu-Bell Welfare Society \& 2 others (2016) eKLR. Kenya Airports Authority v Mitu-Bell Welfare Society \& 2 others (2016) eKLR.
} 
decision in delegating her judicial functions to state agencies and civil society organisations, Pamoja Trust being one of them. ${ }^{54}$ Second, it was the Court of Appeal's decision that as per the doctrine of functus officio, the court decision should be final such that affidavits and pleadings should not be filed after the delivery of the judgement. ${ }^{55}$ And, finally, the Court of Appeal maintained that on the basis of Article 20(5) (c) of the Constitution, the court should not interfere with the decision of a State organ regarding the allocation of available resources only because it is the court assertion that the organ should have reached a different decision. ${ }^{56}$

The Court of Appeal pointed out that Justice Mumbi relied heavily on South African jurisprudence on the matter. She observed in her analysis that Section 26 of the Constitution of South Africa providing for the right to adequate housing was similar to Article 43 of the Kenyan Constitution providing for the same right. ${ }^{57}$ This is not surprising as the drafting of the Kenyan Constitution was inspired to a large extent by the guidelines of the South African Constitution. ${ }^{58}$

This observation on the similarity of the constitutional provisions was drawn from the famous Grootboom case, ${ }^{59}$ similar to the case presented before the Kenyan Court of Appeal. The Constitutional Court of South Africa (Constitutional Court) ruled in favour of people in informal settlements as Section 26 of the South African Constitution was applicable to their situation. ${ }^{60}$ The Constitutional Court went further to state that there is an obligation for the South African government to expeditiously and effectively establish a public housing programme that ought to be reasonably implemented. ${ }^{61}$ The Constitutional Court did not decide on the peculiarities of such programmes but left such decision to the discretion of the executive so as to avoid taking a more managerial position and encroaching upon the functions of the executive. However, the Kenyan Court of Appeal maintained that in South Africa there are legislations that require the government to ensure that people from informal settlements are provided with adequate housing. Yet, even if the Constitution requires the State to take reasonable legislative measures and other measures to

\footnotetext{
Kenya Airports Authority v Mitu-Bell Welfare Society \& 2 others (2016) eKLR. Kenya Airports Authority v Mitu-Bell Welfare Society \& 2 others (2016) eKLR. Kenya Airports Authority v Mitu-Bell Welfare Society \& 2 others (2016) eKLR. Kenya Airports Authority v Mitu-Bell Welfare Society \& 2 others (2016) eKLR. Kaguongo W 'Introductory note on Kenya', 6.

Kenya Airports Authority v Mitu-Bell Welfare Society \& 2 others (2016) eKLR. Kenya Airports Authority v Mitu-Bell Welfare Society \& 2 others (2016) eKLR.

Government of the Republic of South Africa and Others v Grootboom and Others (2000), Constitutional Court of South Africa.
} 
enforce socio-economic rights progressively, Kenya does not have any legislation requiring the state to ensure the settlement of landless Kenyans. ${ }^{62}$

\section{On Preserving the Doctrine of Separation of Powers: Critiques}

\section{i. On how the Executive should carry out its functions}

In agreement with the Court of Appeal, this study observes that Justice Mumbi erred in her decision by interfering with the functions of the executiveby ordering civil society, including Pamoja Trust as well as specific State agencies, to assist the State in arriving at appropriate policies and programmes aimed at addressing the grievances of people living in informal settlements. ${ }^{63}$ Compelling the Government to go specifically to these bodies was a violation of the doctrine of separation of powers because 'the constitutional duty of the courts (in regard of structural interdicts) is not to tell government officials how to effectuate the right (to have access to adequate housing) of the Constitution, but merely to ensure that they do take reasonable measures to make the system effective. ${ }^{64}$ Justice Mumbi's decision, on the other hand, risked the court taking a more bureaucratic role regarding matters of the State which necessarily falls outside the Court's powers and functions.

However, Justice Mumbi applied a type of structural interdict - the expert remedial system- which was discussed in the previous sectionand which requires that a case before the judge be referred to an expert or a panel of experts who have the mandate to develop a remedy according to their expertise in the relevant field. ${ }^{65}$ One has good reason to say that this particular type of structural interdict is indeed a threat to the doctrine of separation of powers as it often requires the judge to delegate their judicial power to the expert(s). ${ }^{66}$ Another threat that it causes to the doctrine of separation of powers is that it withdraws from the executive discretion pertaining to which policies or programmes are most suitable to implement, and therefore interferes with policy-making and bears budgetary

\footnotetext{
Kenya Airports Authority v Mitu-Bell Welfare Society \& 2 others (2016) eKLR. Kenya Airports Authority v Mitu-Bell Welfare Society \& 2 others (2016) eKLR. Magidimisi v Premier of the E. Cape E Others (2006) High Court of South Africa.

65 Mbazira C, 'Litigating Socio-economic-Economic Rights in South Africa- A choice between corrective and retributive justice', Pretoria University Law Press, Cape Town, 2009, 188.

${ }_{66}$ Mbazira C, 'Litigating Socio-economic-Economic Rights in South Africa- A choice between corrective and retributive justice', 188.
} 
implications which are the province of the executive and the legislature. ${ }^{67}$ The most notable deleterious effect of this model lies in its discredit of the constitutional enterprise by imposing upon the executive and legislative policies that may not be reflective of pertinent state needs resulting in a possible breakdown of state resources. It follows that if this type of structural interdict fails to achieve the balance sought by structural interdicts as advanced in the Brown case, Justice Mumbi's application of it was an encroachment on the doctrine of separation of powers.

The Court of Appeal spotted this overstep, ${ }^{68}$ but instead of rectifying it so as to bring its decision in line with the spirit of structural interdicts as laid down in the Brown case, it interpreted it as a transfer of judicial power to Pamoja Trust, and the other unnamed state agencies and state organs, which it found unconstitutional and a breach of the doctrine of separation of powers since it was determining how the Executive should carry out its functions. The doctrine of separation of powers remains a hallmark of an efficient democracy, with the Constitution clearly outlining the functions of each of the arms of government. It is from this lens that the arguments purporting that structural interdicts are an encroachment of the said doctrine are justifiable to some extent, seeing as it would entail the Judiciary 'telling' the Executive how to perform its functions. However, one can only begin to truly understand the impact resulting from the use of structural interdicts on the doctrine of separation of powers from an in-depth analysis of the two.

The doctrine of separation of powers entails the idea of power-sharing between the Executive, the Legislature and the Judiciary to ensure essential checks and balances with the aim of curbing the abuse of power by any one of the three arms. ${ }^{69}$ According to this arrangement, the Legislature is granted the powers to make laws; the Judiciary to interpret and apply laws; and the Executive to implement laws. ${ }^{70}$ However, it is also worth noting that the separation of powers is not absolute and that there is 'no sovereign, unlimited power in a constitutional democracy'. ${ }^{71}$ From this flow of thought, it stands to reason that this doctrine would thus place a hypothetical barrier on courts (the Judiciary)

\footnotetext{
Mbazira C, 'Litigating Socio-economic-Economic Rights in South Africa', 188-189.

Kenya Airports Authority v Mitu-Bell Welfare Society \& 2 others (2016) eKLR.

69 Fombad C, 'The separation of powers and constitutionalism in Africa: The case of Botswana' 25(2), Boston College Third World Law Journal, 2005, 304.

70 Wiles E, 'Aspirational principles or enforceable rights? The future for socio-economic rights in national law' 22(1) American University International Law Review, 2006, 43.

71 Ngang C, Judicial enforcement of socio-economic-economic rights in South Africa and the separation of powers objection: The obligation to take 'other measures' 14(2) African Human Rights Law Journal, 2014, 659.
} 
using structural interdicts, especially if they find themselves in a relatively new democratic atmosphere such as the one in Kenya. This presents a series of questions pertaining to whether the courts should get involved in the enforcement of socio-economic rights, as well as the trade-offs that are necessary to balance the role of courts and political institutions. ${ }^{72}$

The political organs of the state, specifically the Executive, usually bear the responsibility to ensure the progressive realisation of socio-economic rights. However, it is equally possible for that realisation to happen through the courts. This view is supported by Stewart, who argues that courts are mandated to utilise their 'quasi law-making' powers to translate socio-economic rights entrenched in the Constitution into enforceable legal claims. ${ }^{73}$ Judicial enforcement is thus a key strategy for protecting and empowering aggrieved groups, particularly when political channels of realisation become unavailable, ineffective, inaccessible or insufficient. ${ }^{74}$ When this happens, the main contention is that the doctrine of separation of powers becomes blurred or diluted, therefore threatening the very essence and survival of democracy. ${ }^{75}$ This line of thinking makes a compelling case for courts to use structural interdicts.

On the one hand, Ferraz has argued that it is in fact legitimate for courts to encroach into the province of the Executive when necessary. This is because the political decision to give socio-economic rights constitutional recognition also grants the courts power to enforce them. ${ }^{76}$ This argument therefore undercuts the question of the courts' legitimacy in matters of enforcement and thus negates any supposed breach of the doctrine of separation of powers. ${ }^{77}$ On the other hand, strong proponents of the doctrine of separation of powers have contended that the practice of courts handing out structural interdicts is intrusive and politically incorrect. ${ }^{78}$

72 Butt D, Transformative constitutionalism and socio-economic rights: Courts and the making of public policy and the social contract revisited, 11 June 2008, 2.

73 Stewart L 'Adjudicating socio-economic-economic rights under a transformative constitution' 28(3) Penn State International Law Review, 2010, 506.

74 See generally Cumming $S$ and Rhodes D 'Public interest litigation: Insights from theory and practice' 36(4) Fordham Urban Law Journal, 2009.

75 Brennan M 'To adjudicate and enforce socio-economic-economic rights: South Africa proves that domestic courts are a viable option' 9(1) Queensland University of Technology Law and Justice Journal, 2009, 72.

76 Ferraz $\mathrm{O}$ 'Between usurpation and abdication? The right to health in the courts of Brazil and South Africa' Health and Human Rights Journal, $2009-<$ https://www.hhrjournal.org/2013/08/theright-to-health-in-the-courts-of-brazil-worsening-health-inequities/> on 13 November 2018.

77 Ferraz $\mathrm{O}$ 'Between usurpation and abdication? The right to health in the courts of Brazil and South Africa' Health and Human Rights Journal, $2009-<$ https://www.hhrjournal.org/2013/08/theright-to-health-in-the-courts-of-brazil-worsening-health-inequities/> on 13 November 2018.

78 Ngang C, Judicial enforcement of socio-economic-economic rights in South Africa and the separation of powers objection: The obligation to take 'other measures', 659. 
A common belief is that when courts enforce socio-economic rights through structural interdicts, judges tend to make decisions determining the types of programmes and policies that the government should implement, ${ }^{79}$ as is evident in the Mitu-Bell case. Meanwhile, according to these perceptions, the Judiciary is supposed to interpret and apply the law only and not to make decisions that would have a policy or budgetary implication. ${ }^{80}$ (emphasis ours).

In this regard, the courts have consistently found themselves in a challenging position concerning how to enforce the positive obligations imposed by socioeconomic rights, and at the same time respect the limits of the separation of powers ${ }^{81}$ However, the report back to court model of structural interdicts only requires judges to put in place programmes and policies that may achieve the realisation of a given socio-economic right while leaving the executive with the discretion to determine what types of programmes and policies it should implement. One cannot help but admit that, had the Court of Appeal applied this model, it could have provided proper guidelines on how to enforce socioeconomic rights without infringing on the doctrine of separation of powers.

In the Mitu-Bell case, strictly applying this doctrine has left the enforcement of socio-economic rights out of the equation. The only direction that the court provided was that the Government should be left with the discretion to meet the progressive realisation of socio-economic rights required by the Constitution. ${ }^{82}$

\section{ii. On the progressive realisation of rights}

The Court of Appeal held that the High Court had failed to consider that the appellant has a statutory mandate that does not include the settlement of landless Kenyans and that it was a mistake to rely on the South African case (Grootboom), because in South Africa there are statutory provisions on this: the Housing Act of 1997; the Housing Consumer Protection Measures Act of 1998; and the Prevention of Illegal Eviction From Unlawful Occupation of Land Act of 1998. The Court of Appeal emphasised that, unlike South Africa, Kenya did not have, at the time of its decision, a statute compelling the government to

\footnotetext{
79 Ngang C, 'Judicial enforcement of socio-economic-economic rights in South Africa and the separation of powers objection: The obligation to take 'other measures', 659.

80 Brennan M 'To adjudicate and enforce socio-economic-economic rights: South Africa proves that domestic courts are a viable option', 72.

81 Ngang C, Judicial enforcement of socio-economic-economic rights in South Africa and the separation of powers objection: The obligation to take 'other measures', 665 .

82 Kenya Airports Authority $v$ Mitu-Bell Welfare Society $\& 2$ others (2016) eKLR.
} 
put in place policies and programmes that should facilitate the enjoyment of the right to housing. Consequently, the court should not interfere, otherwise it would be infringing on the constitutionally entrenched doctrine of separation of powers. In addition, the Court noted that the Civil Procedure Act does not allow it to issue supervisory orders (structural interdicts) in order to monitor the executive compliance with its order. ${ }^{83}$

Contrary to the Court of Appeal's stipulation, the Grootboom decision was not primarily informed by the existence of the Housing Act of 1997, the Housing Consumer Protection Measures Act of 1998, or the Prevention of Illegal Eviction from Unlawful Occupation of Land Act of 1998. Rather, it was by the constitutional requirement that socio-economic rights should be enforced. ${ }^{84}$ The Court's use of structural interdicts was thus grounded in the State's constitutional obligation to create programmes and take reasonable measures directed towards the realisation of socio-economic rights.

The concept of 'progressive realisation' was introduced, in its onset, to consider contextual obstacles that the government may face in resource allocation, budgetary concerns and spending. Unfortunately, in lending a helping hand towards the government by lessening pressures in the fulfilment of these rights, its broad category and discretionary nature has inadvertently served as a means to encourage a state of inertia. ${ }^{85}$ This is why there is a need for the Judiciary to step in so as to ensure that the government is promoting these rights, depending on the resources available. By analogy, this is how socio-economic rights should be enforced as illustrated in both Brown and Grootboom.

In fact, in Grootboom, the Constitutional Court had occasion to make a pronouncement on the concept of 'progressive realisation' of socio-economic rights which came up when the question of what measures the government had taken arose. The Court addressed this by stating that 'the measures (taken) must establish a coherent public housing programme directed towards the progressive realisation of the right of access to adequate housing within the State's available means'. The Court acknowledged that there is indeed a nexus between the government meeting socio-economic needs and people exercising their civil

\footnotetext{
Kenya Airports Authority v Mitu-Bell Welfare Society \& 2 others (2016) eKLR.

84 Government of the Republic of South Africa and Others v Grootboom and Others (2000), Constitutional Court of South Africa.

85 See Charo Wa Yaa v Jama Abdi Noor and 4 Others (2010), High Court of Kenya (unreported). Klare K, 'Legal Culture and Transformative Constitutionalism', South African Journal on Human Rights,1998, -<https://heinonline.org/HOL/LandingPage?handle=hein.journals/soafjhr14\&div= $17 \&$ id $=$ \&page $=>$ on 15 June 2018.
} 
and political rights; then went ahead to note that the concept of progressive realisation means that the government has 'an obligation to move as expeditiously and effectively as possible towards (a) goal'. ${ }^{86}$

At this juncture, it is evident that the 'progressive realisation' can best be achieved through structural interdicts. This is because an abandonment of judicial enforcement risks constitutional protections being reduced to 'parchment barriers', mere words on paper lacking any real efficacy. ${ }^{87}$ Unfortunately, the importance of structural interdicts in securing socio-economic rights does not seem to be shared by the Kenyan Court of Appeal.

\section{iii. Effect of the Court of Appeal decision}

The effect of this type of jurisprudence, that is the Court of Appeal decision, is monumental as not only does the ratio decidendi, but also, the principle that has emerged in the case. What is clear from the Court of Appeal judgment is that not only will the human right at issue in the case not be remedied, the right of access to adequate housing, ${ }^{88}$ but also a body of human rights whose enforcement will be covered by such a principle. Even if this was a case concerning the socio-economic right to accessible and adequate housing, the jurisprudence it has developed is that the enforcement of other similar socioeconomic rights, ${ }^{89}$ cannot be achieved through application of structural interdicts. This is unfortunate given that structural interdicts are the most effective, if not the only, way of enforcing socio-economic rights. ${ }^{90}$

\section{Concluding Remarks}

This study has analysed the Court of Appeal's decision in the MituBell Case. This appeal was mainly on the ground that the High Court judge's reliance on structural interdicts to enforce socio-economic rights infringed upon the doctrine of separation of powers. Structural interdicts have various models. This study has demonstrated that the model applied by the High Court judge - the

\footnotetext{
Government of the Republic of South Africa v Grootboom, 11 BCLR 1169 (CC) (2000).

Kenya Airports Authority v Mitu-Bell Welfare Society \& 2 others (2016) eKLR.

Kenya Airports Authority v Mitu-Bell Welfare Society \& 2 others (2016) eKLR.

Article 24, Constitution of Kenya (2010).

Thus far, there seems to be no other means of enforcing socio-economic rights that can be found in literature other than structural interdicts.
} 
expert remedial formulation model - was indeed in breach of the doctrine of separation of powers. The reason for this is that it interferes with the functions of the executive arm of government by dictating how they should perform such functions. However, there exist other types of structural interdicts, such as the report back to court model, which do not affect the doctrine of separation of powers since they leave the executive with the discretion to put in place policies and programmes that may redress a particular violation of socio-economic rights. Sadly, the Court of Appeal did not analyse these various models of structural interdicts in identifying the one best suited to the case at hand. The Court opined that the executive and the legislative should be left with the discretion to enforce these rights progressively, an outcome which may be abused in the absence of judicial intervention.

The distinctive nature of structural interdicts is vested in their respect of 'democratic prerogatives' in maintaining sensitivity to limited public resources, whilst initiating government action to those whose minimal needs are not being met. ${ }^{91}$ Their application embraces an articulate balance of enforcement while simultaneously preserving the doctrine of separation of powers. Therefore, the Court of Appeal's decision to strike them out of the Kenyan jurisprudence on the basis that one flawed model of structural interdicts, the expert remedial formulation model, acted in violation of the doctrine of separation of powers is fatal to the future of socio-economic rights whose existence is now relegated to aspirations lacking substantive enforcement value.

As averred by Madison in the Federalist Papers, 'the efficacy of (a constitutional) provision has been greatly overrated...some more adequate defence is indispensably necessary for the feebler, against the more powerful members of the government'. ${ }^{92}$ It is therefore not enough to stipulate socio-economic rights and confine them solely to the province of the executive and legislature. Where there is a failure by government to adhere to constitutional standards, a sufficient guard should be available in protecting against administrative arbitrariness and/ or inaction which is at present best produced using structural interdicts. It is therefore paramount that Kenyan courts reconsider the ratio in the Mitu-Bell to ensure that socio-economic rights do not fall prey to non-enforcement.

\footnotetext{
91 Sustein C, 'Social and Economic Rights? Lessons from South Africa' Coase- Sandor Institute for Law and Economics, John M. Olin Law and Economics Working Paper No. 124, 2001, 131 http://www.law.uchicago.edu/Lawecon/index.html on 8 November 2018.

92 Madison J, 'The Federalist Papers' No. 48, 1788 — http://avalon.law.yale.edu/18th_century/fed48. asp on 7 November 2018.
} 
